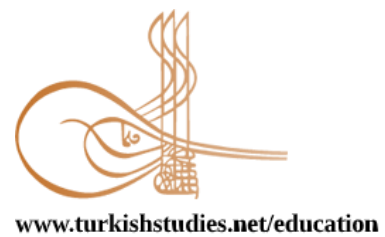

Turkish Studies - Educational Sciences

eISSN: 2667-5609

Research Article / Araştırma Makalesi

\title{
Değer Eğitimi Konusunda Yapılmış Lisansüstü Tezlerin İncelenmesi
}

\author{
Examination of Graduate Theses on Value Education
}

\author{
Şerif Ali Değirmençay ${ }^{*}$ - İlkay Yeşiltaş**
}

\begin{abstract}
This study was conducted in order to reveal approaches related to values education in Turkey. This research was conducted by way of document analysis within scope of the qualitative research approach. Master's theses published in Turkey were analyzed by way of content analysis. The research's population consists of master's theses and doctoral dissertations on values education, prepared from January 2000 to May 2020 in Turkey, of which full text can be accessed via YOK (Higher Education Board) TEZ page. As a result of the literature review, 38 theses on values education were reviewed, including 5 doctoral dissertations and 33 master's theses. Theses were subjected to content analysis with publication classification and suggestion classification forms so developed. Data gained were analyzed using SPPS 21.statistics program. Results of the study were presented as frequency and percentage in graphs and tables in a descriptive fashion. It was observed that the highest number of theses on values education were prepared for the Turkish field whereas the lowest number of such theses concerned life sciences, mathematics, physical education and sports. It was found out that a vast majority of studies were conducted after 2015, qualitative research method was used at these studies to a great extent, and scales and interview forms were frequently used as the data collection tool. It was ascertained that, during the review of suggestions part, more suggestions were presented to the Ministry of National Education and such suggestions were about provision of education and enhancement of reference books. In the light of data gained, with regards to current status of values education researches, MoNE and researchers were provided with recommendations on support for, increase and diversification of studies of this kind and on what research directions should be like.
\end{abstract}

Structured Abstract: Introduction: Value is an attitude showing persons' personality characteristics and direction of choices which arises from the place of a thing within other beings of the same type, the use of rules believed and accepted by the society as a scale and comparison of behaviors of the individual with such scale. Although the number of studies conducted in the field of values education increases, it may be said that they have started to create an irregular pile. It is quite important for both readers and researchers to render such pile meaningful. This study aimed to conduct the content analysis of dissertations on values education prepared at the level of the secondary school from January 2000 to May 2020 and make a contribution to the field.

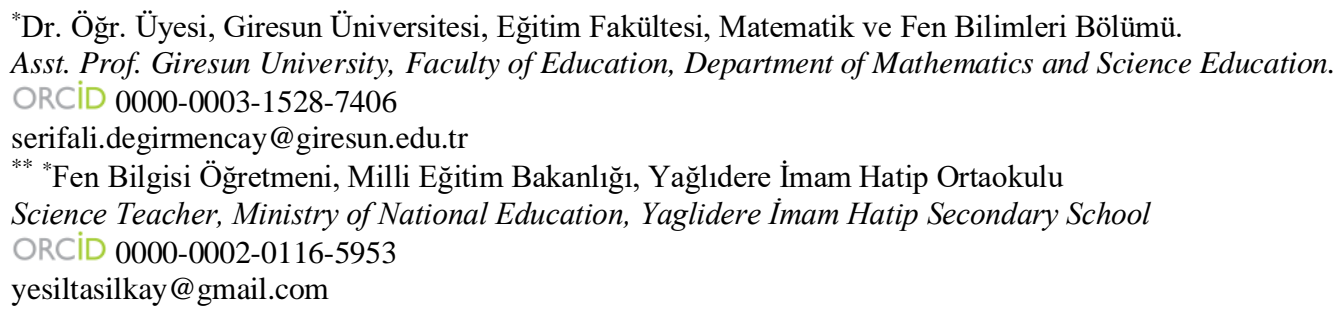

*Dr. Öğr. Üyesi, Giresun Üniversitesi, Eğitim Fakültesi, Matematik ve Fen Bilimleri Bölümü. Asst. Prof. Giresun University, Faculty of Education, Department of Mathematics and Science Education. ORCID 0000-0003-1528-7406 serifali.degirmencay@giresun.edu.tr

*** *Fen Bilgisi Öğretmeni, Milli Eğitim Bakanlı̆̆ı, Yağlıdere İmam Hatip Ortaokulu Science Teacher, Ministry of National Education, Yaglidere Imam Hatip Secondary School ORCID 0000-0002-0116-5953 yesiltasilkay@gmail.com

Cite as/ Atıf: Değirmençay, Ş. A. \& Yeşiltaş, İ. (2020). Değer eğitimi konusunda yapılmış lisansüstü tezlerin incelenmesi. Turkish Studies-Education, 15(4), 2513-2530.https://dx.doi.org/10.47423/TurkishStudies.44457

Received/Geliş: 23 June/Haziran 2020

Accepted/Kabul:27 August/Ağustos 2020

Copyright (C) INTAC LTD, Turkey 
Method: The research's sample consists of 33 master's theses, 5 doctoral dissertations on values education, prepared fromJanuary 2000 to May 2020 in Turkey, of which full text can be accessed via YOKTEZ page, whereas master's thesis and doctoral dissertations prepared at the level of secondary school constitute the research's population. Theses well-suited to the purpose of the study were included in the research.

This research was conducted by way of document analysis within scope of the qualitative research approach. Data were analyzed through content analysis. Theses were subjected to the content analysis. As the data collection tool, publication classification and suggestion classification form, developed by the researcher, composed of 8 parts each. Forms were revised, as necessary, by reviewing scales and forms in similar studies, and they were developed at a level for comprehensive analysis. Theses were examined independently of one another and data were coded and exported to SPSS 21 package software.

Findings: According to findings derived, it was observed that theses reviewed were, predominantly, on Social Sciences, Turkish, Education of Religion and Ethics, whereas Life Sciences, Mathematics and Physical Education and Sports are the fields for which the least number of studies were conducted. No thesis was encountered for certain fields. Research patterns of theses is mostly case study for qualitative studies, scanning study for quantitative studies, and parallel mixed pattern for mixed studies. When the study sample or group selected as the study group or materials of studies are examined, it was observed that the number of teachers and studies examining reference books was high. In those theses included in this research, the value or the group of values on which the greatest emphasis was put is values included in programs. Studies covering values in programs are proportionately followed by values in resources, and researches studying value perceptions of educators, respectively. It was observed that different analysis methods were used on theses reviewed according to analysis methods. The content analysis was used in qualitative studies and all studies at a high rate. When theses related to values education are examined, two categories were ascertained as suggestions for the Ministry of National Education and the third parties other than the Ministry. Although ratio of suggestions for the Ministry and third parties other than the ministry is close to one another, the ratio of suggestions for the ministry is higher. Upon conclusion of the research, suggestions presented include the fact that studies in the field of values education are not sufficient, such studies should be increased in number in the field of life sciences and sports sciences, classification forms used for these studies can be diversified, studies whereby parents may be used as the sample group can be increased, and MoNE should support studies of this kind.

Results: When research methods employed in studies are analyzed, it was discovered that the qualitative research method is the method used the most in the theses with 50\%, whereas the mixed research method was used the lest with $21.1 \%$. Reason for the foregoing could be that values education studies produce better results for the qualitative method. The purpose of a study that adopted a qualitative method is ability to gain in-depth knowledge on the subject matter. To that end, the researcher asks additional questions and tries to reveal personal views of the participant.

When the study sample or group selected as the study group or materials of studies are examined in these theses, the rate of studies examining teachers and reference books was the highest with $28.9 \%$ and ones focusing on students and parents remained at the lowest rate with $2.6 \%$. The number of researches where parents were studied as the sample group is quite low. In their study by Kapkın et al., whereby theses on values education prepared from 1991 to 2017 were reviewed, they discovered that large number of studies were conducted with students, teachers and administrators whereas studies conducted with parents were minimal. In a study where reference books selected as the sample for studies on life sciences were examined in respect of values education, it was concluded that activities of values education included in environment education subjects were insufficient and failed to make students adopt such values.

Suggestions: Following suggestions were presented in line with conclusions of researches. When looking into researches, it was discovered that the number of theses where parents were studied as the sample group is quite low. An increase in researches whereby parents can be used as the sample group can be suggested.In the study conducted, data collected in connection with theses were analyzed with 8 classifications. These sub problems can be higher in number or could be diversified with different problems. For example, "teaching materials" are selected as the classification type and if materials are examined in details, it may be possible to gain in-depth information about activities planned for values education. Another example of classification could be related to "evaluation techniques used for establishing changes occurring

Turkish Studies - Education, 15(4) 
in achievement and behaviors of students." Thus, it may be possible to ascertain evaluation criteria of teachers regarding behaviors in particular and to make a contribution to values education.From among theses examined within scope of this research, no thesis was encountered which reviews reference books of life sciences in terms of values education. It may be suggested that a study be conducted for books of life sciences. Many suggestions regarding "values education" submitted to the Ministry of National Education were ascertained in the "suggestions" part of the classification used in the form so used in this study. It is essential that our Ministry be informed about these studies. In this sense, it may be suggested that studies with "suggestion" classification be supported, as well. Thus, it is believed that information could be gathered more systematically owing to studies of this kind. The number of studies aiming to provide values education with an interdisciplinary organization, from among theses so examined, is quite limited. Number of such studies could be increased. Number of studies conducted in the field of Life Sciences and Sports Sciences seems to be low. It may be suggested that studies regarding life sciences which have one-on-one interaction with the science, society and environment be enriched.

Keywords: Science Education, Value Education, Secondary School, Thesis, Content Analysis.

Öz: Yapılan bu çalışmada, Ülkemizde, değer eğitimi alanında çalışılmış lisansüstü tezlerde tespit edilen kriterlerin ayrıntılı incelenmesi amaçlanmıştır. Çalışma, nitel araştırma yaklaşımı kapsamında doküman analizi yoluyla gerçekleştirilmiştir. $\mathrm{Bu}$ amaç doğrultusunda, Türkiye'de yayınlanan lisansüstü tezler incelenmiş ve içerik analizi yöntemi ile çözümlenmiştir. Ocak 2000-Mayıs 2020 yılları arasında değer eğitimi ile ilgili Türkiye'de yapılmış YÖK TEZ sayfasında tam metnine ulaşılabilen, ortaokul düzeyinde yapılmış, yüksek lisans ve doktora tezleri araştırmanın evrenini oluşturmuştur. Literatür taraması sonucunda değer eğitimi ile ilgili 5 doktora tezi ve 33 yüksek lisans tezi olmak üzere toplam 38 tez taranmıştır. Tezler, geliştirilen yayın sınıflama ve öneri sınıflama formlar ile içerik analizine tabi tutulmuştur. Elde edilen veriler SPPS 21.0 istatistik programı kullanılarak analiz edilmiştir. Çalışma sonuçları, frekans ve yüzde olarak betimsel biçimde grafik ve tablolarda sunulmuştur. Buna göre; değer eğitimine yönelik yapılmıș tezlerin, en yüksek oranda Türkçe alanında, en düşük oranda ise fen bilimleri, matematik, beden eğitimi ve spor alanlarında yapıldığı tespit edilmiştir. Çalışmaların büyük bir çoğunluğunun 2015 yılından sonra yapıldı̆̆ı, çalışmalarda nitel araştırma yönteminin yüksek oranda kullanıldığı, veri toplama aracı olarak ölçeklerin ve görüşme formlarının sıklıkla kullanıldığı tespit edilmiştir. Tezlerin, öneriler bölümleri de analiz edilmiş ve buna göre; Milli Eğitim Bakanlığına daha çok önerilerin yapıldığı ve bu önerilerde, eğitimlerin verilmesi ve kaynak kitapların geliştirilmesi gerektiğine yönelik olduğu tespit edilmiştir. Bu veriler ışığında, MEB'na ve araştırmacılara, çalışmaların desteklenmesi, çeşitlendirilmesi ve araştırma yönelimlerin neler olması gerektiği yönünde tavsiyelerde bulunulmuştur.

Anahtar Kelimeler: Fen Bilimleri, Değer Eğitimi, Ortaokul, Tez, İçerik Analizi.

\section{Giriş}

Makale Eğitim kişinin davranış biçimini değiştiren en önemli etkendir. Sokrates'e göre eğitimin amacı toplumu inaksal ve ön yargıdan uzak, evrensel değerleri taşıyabilen değer doğruları olan bireyler yetiştirebilmektir. Platon'a göre eğitim sorumluluğa sahip bireyler yetiştirmek suretiyle adil bir topluma ve adil bir devlet sistemine erişebilmektir. John Locke 'a göre ise eğitim insanların huzurunu ve mutluluğunu ileriye götürecek bireyler yetiştirme amacını taşımalıdır. Bütün bu amaç tanımları şunu gösteriyor ki eğitimle ilgili kavramlarının toplumsal değer kavramları ile derin bağları bulunmaktadır (Çüçen, 2011).

Türk Milli Eğitim Sistemi analiz edildiğinde öğretim programlarında yer alan kazanımların genellikle bilişsel alana yönelik olduğu, duyuşsal hedeflerin ve duyuşsal kazanımların görece az olduğu ve programda örtük şekilde yer aldığı görülmektedir. Milli Eğitim sisteminde sınırlı ölçüde eğitim programlarında yer alan duyuşsal alana ait kazanımların ve hedeflerin kazanılıp kazanılmadığını ölçecek bir ölçme sistemi ve ölçme aracının olmadığını söyleyebiliriz. Eğitim programlarında yer alan bilişsel kazanımlar her dönem belli aralıklarla farklı ölçme araçları ile 
ölçülebilir iken, duyuşsal alana ait kazanımlar sadece dönem sonu verilen davranış notları ile gözleme tabi tutulmaktadır (Toktemir, 2007).

Değer; bir şeyin aynı türden olan diğer varlıklarların içerisindeki yeri,inanılan ve toplum tarafından kabul gören kuralların ölçek olarak kullanılması, bu ölçek ile bireyin davranışlarının karşılaştırmak suretiyle ortaya çıkan kişilerin kişilik özellikleri ve tercihlerin yönünü gösteren bir tutumdur (Altun, 2003). Değerler bireylerin var olan inanç örüntüleridir. Değerler tamamen nesnel, içerisinde duygu barındırmayan düşünce niteliğinde değillerdir. Değer kişinin hedefleri ve bu hedeflere nasıl ulaştığıyla alakalıdır. Değer kavramı kişinin dönemlik eylem ve düşüncelerinin üzerindedir. Kişide var olan değerler bir durumda kişinin nasıl bir davranış sergileyeceğini belirleyen en önemli içsel güçtür. Değerler taşıdıkları anlamlara göre kendi aralarında kademelendirilirler. Kademelendirilen değerler gruplandırılır ve bir değer grubu sistemi oluşturulur. Değer değişime açık yapılardır. Zamanla değer algıları ve değer öncelikleri değişkenlik gösterir (Kağıtçıbaşi ve Kuşdil, 2000).

Milli Eğitim Bakanlığı'na göre değerler; kökleri geleneklerimiz ve günümüz içerisinde olan dalları geleceği kucaklayan ilkeler bütünüdür. İnsani özelliklerimizi kazanmamızı sağlayan değerler hayatta karşılaştığımız zorluklara ve engellere karşı direnmemizi sağlayan içsel gücün kaynağıdır. Bu sebepten eğitim sistemimiz her bireye eğitim sistemi içerisinde değer katmayı hedeflemektedir (MEB, 2018).Öğretim programlarında değerlerin öğretiminin nasıl yapılacağına net bir şekilde yer verilmemiştir. Bu durum okullarda değer eğitiminin yapılmadığ gelmez. Öğretmenleri sınıflarında oluşturdukları ortam,iletişim özellikleri,davranışları,öğretmenlerin diğer öğretmenlerle ilşkileri okullarda değer eğitiminin gizil olarak verildiği durumlardan bazılarıdır. Öğretmenler bu davranışlarıyla değerlere vurgu yaparlar. Değer eğitiminin resmi eğitimin bir öğesi olarak sistematik bir şekilde öğrencilere verilmesi önem arz etmektedir (Doğanay, 2006). Öğretim programlarımızda değer eğitimi ayrı bir program içerisinde değerlendirilmemiştir. Değer eğitimi üniteler,kazanımlarla bütünleştirilerek bütünlük ruhu içerisinde işlenmelidir (MEB, 2018).

\section{Literatür incelemesi}

Değerler eğitimi ile ilgili literatürde yer alan çalışmalar; değer eğitimi yönelimleri, akımları inceleyen, farklı amaçlar ile öğretmen görüşlerinin alındığı, kaynak kitaplar, öğretim programları ve diğer materyallerin incelendiği, öğretmen adaylarının incelendiği, yeni yaklaşımlar ve farklı yöntemlerin denendiği, velilerin incelendiği ve derleyici çalışmalar olarak sınıflandırılmaktadır.

Literatürde değer eğitimi yönelimlerini, değerler eğitimi akımlarını, değer sosyolojisi açısından öğretim programının incelendiği çalışmalarda, değer eğitiminde, farklı akımların olduğu, her bir akımda öncelikli değerlerin farklı olduğu, etkili bir değer eğitimi için bu akımların beraber kullanılması gerektiğine yönelik görüşler yer almaktadır (Akbaş, 2008; Yazıc1, 2006; Yurtsever, 2018). Değerler eğitimiyle alakalı, öğretmenlerin değer yönelimlerinin araştırıldığı, öğretmenlerin değer eğitimi ve öğretim programlarıyla alakalı görüşlerinin alındığı çalışmalar oldukça fazladır. Öğretmenlerin değer yönelimlerinin araştırıldığı çalışmalar; cinsiyet, branş, kıdem, çalışılan okul seviyesi, mesleği sevme, mesleğe saygı gibi değişkenlere göre incelendiği çalışmalardır. (Ateş, 2013; Başç1, 2012; Baysal, 2013; Dinçer ve Gözel, 2019; Görgüt, 2015; K1lcan, 2010; Koç 2015; Özdaş, 2013; Özdamar, 2017; Özkemahl1, 2019; Sezer, 2008; Şentürk, 2019; Taymur, 2019; Ulusoy, 2010).

Değer eğitimi konusunda, kaynak kitapların, öğretim programlarının ve diğer materyallerin incelendiği çalışmalarda ise; kaynak kitaplar ve diğer kitaplarda yer verilen değerlerin sıklığı, görsellerin ve metinlerin incelenmesi,yer verilme durumlarının karşılaştırılması, farklı ülkelerin kaynak kitaplarının karşılaştıılması gibi konularının öne çıktığı görülmekle birlikte, tezlerin, Rafadan Tayfa çizgi filminin incelenmesi, programlarda yer alan değer eğitimi etkinlikleri konularında da yapıldığı görülmüştür (Akyol, 2010; Baytaş, 2019; Ecerkale, 2019; Kahya, 2018; 
Kantar, 2014; Özcan, 2019; Maden, 2017; Özenç, 2019; Saka, 2014; Serikkhan, 2018; Şahin, 2019; Yildiz, 2019).

Değerler eğitimi konusunda incelenen tezlerde, öğretmen adaylarını inceleyen çalışmaların oldukça az olduğu tespit edilmiştir. Elde edilen tezlerde, öğretmen adaylarının değer algıları, adayların cinsiyet, mezun olunan okul, anne- baba eğitim durumu gibi değişkenlere göre değer yönelimleri incelenmiştir (Oğuz, 2012; Şahin, 2013).

Son y1llarda, değer eğitiminde materyal kullanma, yeni yöntemler deneme, eğitim programı geliştirme çalışmaları artış göstermektedir. Bu çalışmalarda, değer eğitiminde drama kullanma, bütünleştirilmiş değer eğitimi faaliyetleri ve eğitim programı geliştirme çalışmaları yer almaktadır (Aköz, 2018; Engin,2014; Ertürk, 2019; Çakmak, 2019; Çiçen, 2019; Herdem, 2016; Karacaoğlu, 2018; Katılmış, 2010; Öztekin Ağır, 2017;Uğurlu, 2019).

Alanyazında değerler eğitimi konusunda yapılan çalışmaları derleyici çalışmalar da bulunmaktadır. $\mathrm{Bu}$ çalışmalarda, değerler eğitimi alanında yapılan çalışmalar farklı alt problemlerde incelenmiş, çalışma sonuçları yüzde, frekans, tablo ve grafiklerle sunulmuştur (Balcı, 2008; Elbir \& Bağc1, 2013; Gündüz vd, 2017; Kapkın vd, 2018).

İncelenen literatürde değerler eğitimi alanında velileri inceleyen çalışmalarınoldukça sınırlı olduğu tespit edilmiştir.Bu çalışmalardan biri olan Uğurlu (2012) çalışmasında, 7.sınıf öğrenci velilerinin; okullardaki değer eğitimi hakkındaki görüşleri araștırılmıștır.Fen eğitimi alanında yapılan değerler eğitimine yönelik çalışmalar incelendiğinde söz konusu çalışmaların genellikle öğretim programlarında yeralan değer eğitimine yönelik çalışmalar olduğu görülmektedir. Fen eğitimi alanında öğretmenlerin değer yargılarına, Fen Bilimleri kaynak kitaplarındaki değerlere, Fen projelerinde yer alan değerlere yönelik çalışmalar ve değer eğitimiyle alakalı deneysel araştırmalar bulunmaktadır. Bu tür çalışmalar içerisinde Fen Bilimleri kaynak kitaplarını değer eğitimi bakımından inceleyen çalışmalar çok nadir bulunmaktadır (Aktaş \& Bozdoğan, 2016; Çeçen vd, 2013; Deveci, 2018; Demirci Güler \& Açıkgöz, 2019; Gömleksiz \&Bulut,2007; Gündüz \& Bağc1, 2019; Herdem, 2016; İdin \& Aydoğdu, 2017; Laçin Şimşek, 2004; Oğuz, 2012; Şentürk, 2019; Türker, 2019).

\section{Yöntem}

Çalışma, nitel araştırma yaklaşımı kapsamında doküman analizi yoluyla gerçekleştirilmiştir. Çalışmada, güncel olması açısından, Ocak 2000- Mayıs 2020 yılları arasındaki tezler taranmıştır. Taranan tezler, ortaokul düzeyindeyapılmış olanlar ve YÖKTEZ sayfasında tam metinlerinin ulaşıldığı 33 yüksek lisans tezi ve 5 doktora tezini oluşturmuştur. Ulaşılan bu tezler içerik analizi ile çözümlenmiştir. İçerik analizi; belli kurallara bağlı kalarak bir metnin daha küçük alt parçalara sistematik bir ş̧ekilde ayrılmasını hedefleyen, tekrarlanabilir analiz türüdür (Büyüköztürk vd, 2019). Veri toplama araçlar olarak, araştırmacı tarafından geliştirilen ve 8 er bölümden oluşan yayın sınıflama ve öneri sınıflama formları kullanılmıştır. Formlar, benzer çalışmalarda kullanılan ölçekler incelenerek gerekli düzenlemeleri yapılmış, kapsamlı analiz edebilecek düzende geliștirilmiştir. Buna göre; yayın sınıflama formunda tezlerin; yıllara göre, ders branşlarına göre, incelenen grup ya da materyale göre, kullanılanaraştırma yöntemine göre, araştırma desenlerine göre, öne çıkarılan değer ya da değer gruplarına ve veri analiz yöntemlerine göre dağılımları yer almıştır. Öneri sınıflama formu ise Milli Eğitim Bakanlı̆̆ı'na ve Bakanlık dışına yapılan öneriler olarak iki gruba ayrılmıștır. MEB'na yapılan öneri kategorisinde; öğretim programları, kaynak kitaplar, öğretmenlere verilebilecek eğitimler, okulların teknik imkanı ve materyal desteği kategorileri yer almıştır. MEB dışına yapılan önerilerin çözümlenmesi için; okul yönetimi ve öğretmenlere, velilere, Yüksek Öğretim kurumlarına ve çevreye yönelik yapılan öneri kategorileri yer almıştır. Tezler, birbirinden bağımsız olarak incelenmiş ve veriler kodlanarak SPSS 21 paket programına aktarılmıştır. Veriler yüzdelik ve frekanslara dönüştürülmüş ve tablo ve grafikler halinde sunulmuştur. Çalışmada kullanılan tezlerin literatür taraması iki aşamada 
yapılmıştır. İlk aşamada YÖK'ün Tez Arama Merkezinde normal arama ve gelişmiş arama seçenekleriyle değer, değer eğitimi, kök değerler kelimeleriyle arama yapılmıştır. İkinci aşamada Google, Google Akademik, Ulakbim, Giresun Üniversitesi Kütüphanesi arama motorlarından değer ve değerler eğitimi alanında yapılan çalışmaların kaynakçaları taranmıştır. Taranan kaynakçalarda değerler eğitiminde yapılan tez türünde olan çalışmalar YÖKTEZ de çalışmanın adıyla aranmıştır. Çalışmanın amacına uygun olan tezler araştırmaya dahil edilmiştir. Bu şekilde tezlerin gözden kaçma ihtimali en aza indirilmeye çalışılmıştır.

\section{Bulgular}

Sınıflama formunda yer alan her bir sınıflama çeşitlerine göre tespit edilen bulgular ayrı ayrı başlıklarda aşağıda sunulmuştur.

\section{Yıllara Göre Değer Eğitimi Araştırmaları}

Ocak 2000-Mayıs2020 yılları arasında değer eğitimine yönelik yapılan tezlerin kısmi artışlarla yükseldiği ancak bazı yıllarda çok değişmediğini görülmüştür (Şekil 1), (Tablo 1).

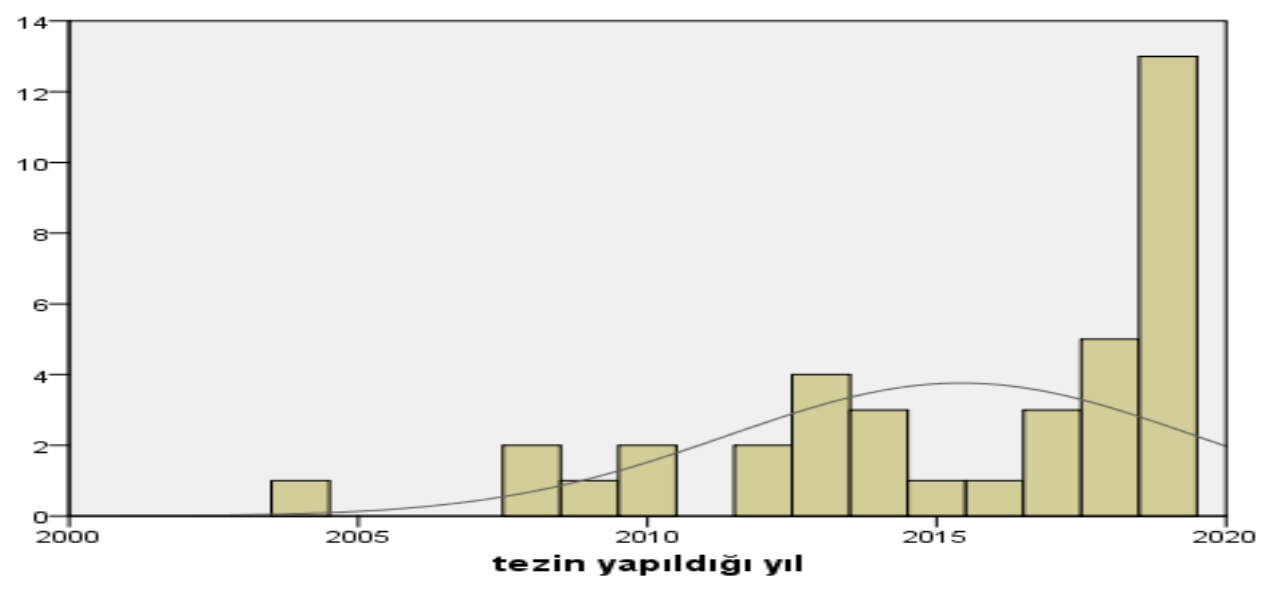

Şekil 1.Tezlerin Y1llara Göre Frekans Değişim Grafiği

Tablo 1. Tezlerin Yayımlandı ̆̆ Y1llara Göre Dağılımı Tablosu

\begin{tabular}{ccc}
\hline Tezin Y11 & $f$ & $\%$ \\
\hline 2004 & 1 & 2,6 \\
2008 & 2 & 5,3 \\
2009 & 1 & 2,6 \\
2010 & 2 & 5,3 \\
2012 & 2 & 5,3 \\
2013 & 4 & 10,5 \\
2014 & 3 & 7,9 \\
2015 & 1 & 2,6 \\
2016 & 1 & 2,6 \\
2017 & 3 & 7,9 \\
2018 & 5 & 13,2 \\
2019 & 13 & 34,2 \\
Toplam & 38 & 100 \\
\hline
\end{tabular}

Not .f = Tezlerin yıllarının frekans değeri ; \% Tezlerin yılarının yüzdelik değeri 
Tablo 1'e göre tezlerin yayımlanma yıllarına göre, en yüksek \%34,2 oranında 2019 yılında, en az ise 2018 yılında ise \%13,2 oranında, büyük bölümünün ise son beş yıl içerisinde yapıldığını söyleyebiliriz. Çalışmada yer alan 5 adet doktora tezlerinin; 2004 (1 adet), 2010 (1 adet), 2012 (1 adet), 2013 (1 adet), 2014 (1 adet) yıllarında yapıldı̆̆ tespit edilmiştir.

\section{Ortaokuldaki Ders Branşlarına Göre Değer Eğitim Araştırmaları}

Çalışmaların Ortaokul ders branşlarına göre dağılımı incelendiğinde en çok çalışmanın soysal bilgiler alanında en az ise fen bilimleri ve beden eğitimi ve spor alanlarında yapıldığ görülmüsstür (Tablo 2).

Tablo 2.İncelenen Tezlerin Branşlara Göre Dağılımı Tablosu

\begin{tabular}{lcc}
\hline Tezin Yapıldı̆̆ı Branş & $f$ & $\%$ \\
\hline Sosyal Bilgiler & 9 & 23,7 \\
Türkçe & 8 & 21,1 \\
Din Kültürü ve Ahlak Bilgisi & 5 & 13,2 \\
Branşı Olmayan Çalışma & 4 & 10,5 \\
Görsel Sanatlar & 3 & 7,9 \\
Disiplinler Arası & 3 & 7,9 \\
Matematik & 2 & 5,3 \\
Fen Bilimleri & 2 & 5,3 \\
Beden Eğitimi ve Spor & 2 & 5,3 \\
Toplam & 38 & 100 \\
\hline
\end{tabular}

En fazla çalışmanın \%23,7 oranında Sosyal Bilgiler branşında yapıldığı ve en az çalışmaların ise yüzde 5,3 oranında Matematik, Fen Bilimleri, Beden Eğitimi ve Spor branşlarında yapıldığı görülmektedir. Doktora tezlerinin ise branşı olmayan (1), disiplinler arası (2), Sosyal Bilgiler (2) alanlarında yapıldığı tespit edilmiştir.

\section{Araştırma Yöntemlerine Göre Değer Eğitim Araştırmaları}

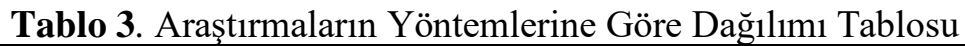

\begin{tabular}{lll}
\hline Araştırma Yöntemi & $f$ & $\%$ \\
\hline Nitel & 19 & 50,0 \\
Nicel & 11 & 28,9 \\
Karma & 8 & 21,1 \\
Toplam & 38 & 100 \\
\hline
\end{tabular}

Tablo 3 de, tezlerde $\% 50,0$ oranla en fazla nitel araştırma yönteminin kullanıldığını, \%28,9 oranında nicel araştırma yönteminin kullanıldığı görülmüştür. Araştırmada yer alan doktora tezlerinin yöntemleri incelendiğinde 3 tezin karma çalışma, 2 tezin nicel çalışma olduğu, doktora tezlerinde nitel bir çalışmanın olmadığı tespit edilmiştir.

\section{Araştırma Desenlerinin Araştırma Yöntemlerine Göre Değer Eğitim Araştırmaları}

Yapılan nitel çalışmalarda, $\% 34,2$ gibi yüksek oranda durum çalışması deseninin kullanıldığı tespit edilmiştir. Eylem araştırmaları \%7,9 oranında, en düşük oranda ise \% $\% 2,6$ kültür analizi çalışmaları yapıldığı görülmüştür (Tablo 4). 
Tablo 4.Araştırmaların Desenlerinin Araştırma Yöntemlerine Göre Dağılımı Tablosu

\begin{tabular}{|c|c|c|c|}
\hline Araştırma Desenleri & Yöntemler & $f$ & $\%$ \\
\hline & Nitel çalışmalar & & \\
\hline Durum çalışması & & 13 & 34,2 \\
\hline Eylem araştırması & & 3 & 7,9 \\
\hline Olgu bilim & & 2 & 5,3 \\
\hline Kültür analizi & & 1 & 2,6 \\
\hline \multirow[t]{2}{*}{ Ara toplam } & & 19 & 50 \\
\hline & Nicel çalışmalar & & \\
\hline Tarama çalışması & & 8 & 21,1 \\
\hline Deneysel çalışma & & 3 & 7,9 \\
\hline \multirow[t]{2}{*}{ Ara toplam } & & 11 & 29 \\
\hline & Karma çalışmalar & & \\
\hline Paralel karma & & 4 & 10,5 \\
\hline Gömülü karma & & 3 & 7,9 \\
\hline Açıklayıcı karma & & 1 & 2,6 \\
\hline Ara toplam & & 8 & 21,3 \\
\hline Genel toplam & & 38 & 100 \\
\hline
\end{tabular}

Nicel çalışmalarda tarama deseni çalışmalar \%21,1 oranındadır. Deneysel çalışmaların tüm çalışmalar içerisindeki oranı \%7,9'dur. Doktora tezlerinde, 2 tezin paralel karma, 1 tezin açıklayıcı karma,1 tezin tarama ve 1 tezin de deneysel çalışma deseninde yapıldığı görülmüştür.

\section{İncelenen Gruplar veya Materyallerin Dağılımına Göre Değer Eğitim Araştırmaları}

İncelelen tezlerde, öğretmenlerin ve kaynak kitapların incelendiği oran \%28,9,doğrudan öğrenciler üzerine yapılan çalışmaların oranı $\% 21,1$ ve en düşük oranda incelenen gruplar ise $\% 2,6$ oranında veliler ve öğretmen adaylarının olduğu görülmüştür (Tablo 5).

Tablo 5.Tezlerde İncelenen Gruplar veya Materyallerin Dağılımı Tablosu

\begin{tabular}{lll}
\hline İncelenen Grup ya da Materyal & $f$ & $\%$ \\
\hline Öğretmenler & 11 & 28,9 \\
Kaynak kitap ve dokümanlar & 11 & 28,9 \\
Ortaokul Öğrencileri & 8 & 21,1 \\
Öğretim Programları & 6 & 15,8 \\
Öğretmen Adayları & 1 & 2,6 \\
Veliler & 1 & 2,6 \\
Toplam & 38 & 100 \\
\hline
\end{tabular}

Doktora tezlerinde ise 3 tezde incelenen grup öğretmenler iken 2 tezde incelenen materyal ise öğretim programları olmuştur. Tablo da elde edilen verilerden 1 adet çalışmanın veliler ile yapılmış olduğu tespit edilmiştir. İlgili tezde inceleme grubu olarak kullanılan Veliler, ortaokul 
seviyesindeki öğrencilerin velilerini içerdiğinden çalışmamıza dahil edilmiştir. Ayrıca araştırmamıza dahil edilen diğer veri, yapılan tezde inceleme grubu olarak kullanılan ve sadece 1 tezde tespit edilen öğretmen adayları grubudur. Çalışmamıza dahil edilmesinin nedeni şöyle açıklanabilir. Sosyal bilgiler dersi sadece ortaokul programında bulunmaktadır. $\mathrm{Bu}$ anlamda öğretmen adaylarının hedef kitlesi ortaokul olduğu için çalışmaya dahil edilmiştir.

\section{Değer Ya da Değer Gruplarına Göre Değer Eğitim Araştırmaları}

Araştırmacıların öne çıkardığı değer grupları, programlardaki değerlere $\% 47,4$ oranı ile en yüksek, eğitimcilerin değer algılarını inceleyen araştırmaların oranı \%15,8 ve doğrudan çalışılan değerlere ise \%13,2 oranında yer verildiği bulunmuştur (Tablo 6).

Tablo 6.Tezlerde Çalışılan Değer Gruplarının Dağılımı Tablosu

\begin{tabular}{lll}
\hline Tezlerde Vurgulanan Değer ya da Değer Grubu & $f$ & $\%$ \\
\hline Programlardaki değerler & 18 & 47,4 \\
Kaynaklardaki değerler & 9 & 23,7 \\
Eğitimcilerin değer algıları & 6 & 15,8 \\
Doğrudan Çalışılan Değer & 5 & 13,2 \\
Toplam & 38 & 100 \\
\hline
\end{tabular}

Çalışma grubu içerisinde yer alan doktora tezlerinde öne çıkarılan değer ya da değer grubu incelendiğinde ise 4 tezde programdaki değerlerin, 1 tezde de eğiticilerin değer algılarının incelendiği görülmüştür.

\section{Analiz Yöntemine Göre Değer Eğitim Araştırmaları}

İncelenen tezlerde, nitel analiz türlerinden içerik analizinin kullanılma oranı $\% 34,2$, betimsel analizin ise kullanılma oranı ise \%10,5 olarak tespit edilmiştir. Betimsel analiz ve içerik analizi aynı anda kullanan çalışmaların oranı ise \%5,3'tür (Tablo 7).

Tablo 7.Tezlerin Analiz Türlerine Göre Dağılımı Tablosu

\begin{tabular}{|c|c|c|c|}
\hline Araştırmalarda kullanılan analiz çeşidi & & $f$ & $\%$ \\
\hline & Nitel Analiz & & \\
\hline İçerik analizi & & 13 & 34,2 \\
\hline Betimsel analiz & & 4 & 10,5 \\
\hline Betimsel ve içerik analizi & & 2 & 5,3 \\
\hline & Nicel Analiz & & \\
\hline \multirow[t]{2}{*}{ İstatistiksel analiz } & & 9 & 23,6 \\
\hline & Karma Analiz & & \\
\hline Betimsel ve istatistiksel analiz & & 6 & 15,7 \\
\hline İçerik ve İstatistiksel analiz & & 3 & 7,9 \\
\hline \multirow{2}{*}{$\begin{array}{l}\text { Betimsel Analiz, İstatistiksel analiz ve içerik } \\
\text { analizi } \\
\text { Toplam }\end{array}$} & & 1 & 2,6 \\
\hline & & 38 & 100 \\
\hline
\end{tabular}

İstatistiksel analizin kullanılma oranı \%23,6'dır. Betimsel analiz ve istatistiksel analizin beraber kullanılma oranı \%15,7'dir. Araştırmalarda \%2,6 ile en az oranda tercih edilen analiz; betimsel analiz, içerik analizi ve istatistiksel analizin üçünün beraber kullanıldığı karma analiz 
çeşidi olmuştur. Çalışmalarda, program olarak, SPSS paket programı 15 tezde, MaxQda 12 programı 1tezde, İteman istatistik ise 1 tezde kullanılmıştır. SPSS paket programı ile yapılan analiz türlerinden; $\mathrm{t}$ testi 15 tezde, mann-whitney u testi 3 tezde, yine wilcoxon işaretli sıralar testi 2 tezde kullanılmıştır. Anova testi 9 tezde, Anova testinin nonoparametrik karş1lığ testi 3 tezde kullanıldığı görülmüsstür. 2 tezde ise poc toc testi olan tukey testi kullanılmıştır.

\section{Araştırmaları}

Milli Eğitim Bakanlığına ve MEB Dışına Yapılan Önerilere Göre Değer Eğitim

Değer eğitimine yönelik ulaşılan tezlerdeki yapılan önerilerin büyük bir kısmı \%51,9 oranında Milli Eğitim Bakanlı̆̆ı'na yapılmıştır. Bakanlığa yapılan önerilerde ise en yüksek oranda $\% 20,4$ ile öğretim programlarıyla ilgili öneriler yeralmaktadır (Tablo 8).

Tablo 8.Tezlerin Öneri Bölümlerinin Sınıflandırılması Tablosu

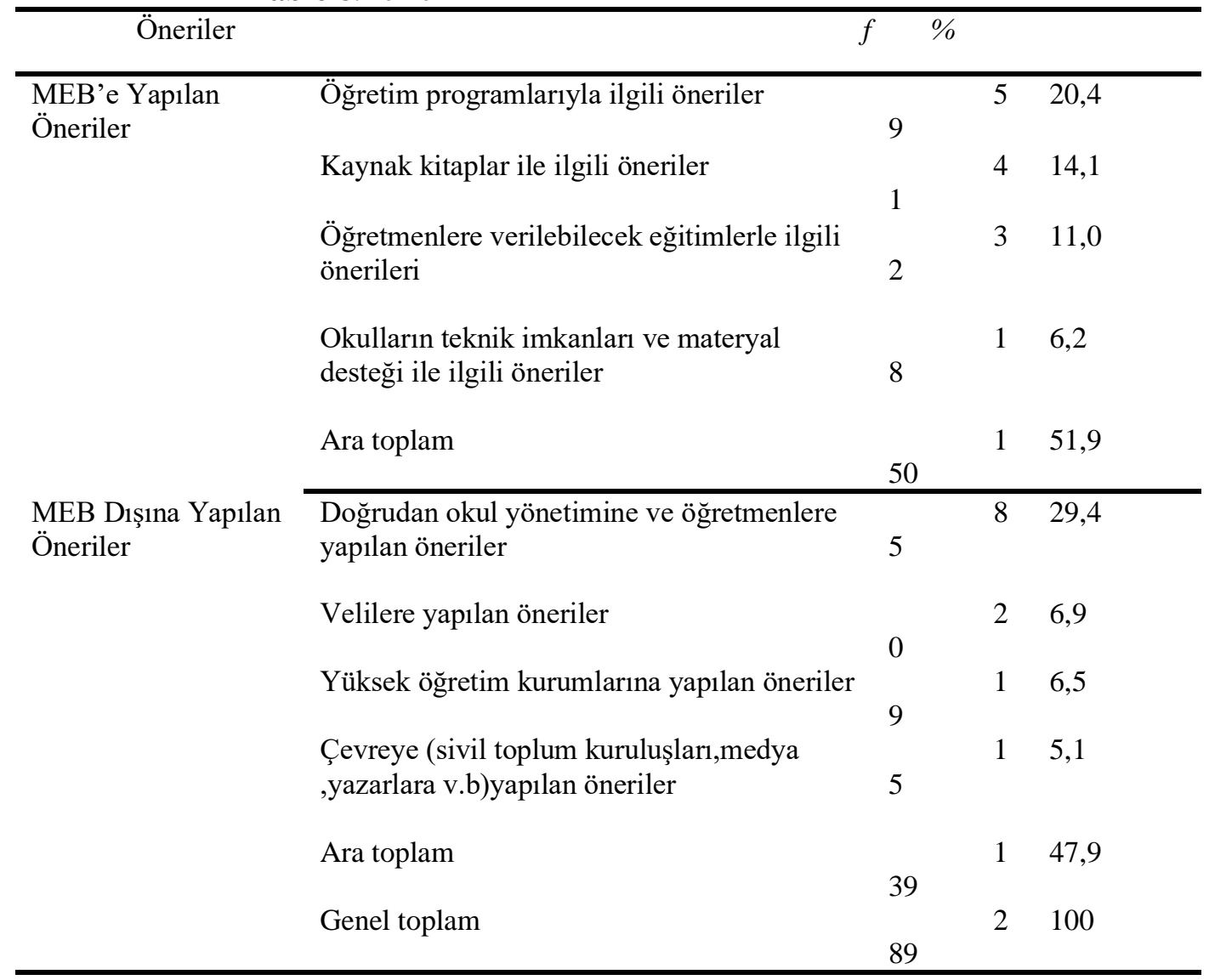

Okulların teknik imkanları ve materyal desteğiyle alakalı olarak Bakanlığı'na yapılan önerinin oranı \%6,2'dir.Mili Eğitim Bakanlığı dışında, eğitim-öğretim ile alakalı diğer öneriler incelendiğinde ise en yüksek oranda $\% 29,4$ okul yönetimlerine ve öğretmenlere yönelik yapılan önerilerdir. En az öneri grubu \%5,1 oranla çevreye yapılan öneriler olmuştur.

\section{Tartışma ve Sonuç}

$\mathrm{Bu}$ araştırmada 38 lisansüstü tez doküman analizi yöntemine göre incelenmiştir. Aşağıda, tespit edilen bulgulara yönelik tartışma ve sonuçlar belirtilmiştir.

Tezlerin yıllara göre dağılımında tezlerin genellikle son 5 yıl içerinde yapıldığı, ancak son 5 yıl içerisinde değerler eğitimi alanında doktora tezinin yapılmadığı görülmüştür. Söz konusu çalışmaların \%34,2'si 2019 yılında yapılmıştır. 2000-2003 yılları arasında bu alanda yapılmış bir 
tez bulunamamıştır. Gündüz vd. (2017), tarafından 2000-2015 yılları arasıda yapılan doktora tezlerini inceledikleri çalışmada 2015 yılında değerler eğitimiyle alakalı yapılmış 9 doktora tezine ulaşmışlardır. Bu sonucun sebebi, lisanüstü tezlerin yapılmış olduğu seviyelerle alakalı olabilir. Bizim çalışmamızda örneklem grubu olarak yalnızca Oratokul seviyesinde yapılmış tezler incelenmiştir. İncelenen tezlerin, çoğunlukla \%23,7 oranında Sosyal Bilgiler, \%21,1 ile Türkçe, Din kültürü ve Ahlak Bilgisi branşlarında yapıldığı, en az çalışmanın ise \%5,3 ile Fen Bilimleri, $\% 5,3$ oranında ise Matematik ve Beden Eğitimi ve Spor branşlarında yapıldığı görülmüştür. Bazı branşlarda ise tez bulunamamıştır. Alan yazında değerler eğitiminin Fen Bilimleri branşında, uygulamaya dönük oldukça az çalışma vardır. Fen Bilimleri dersi bünyesinde değerler eğitimi alanı içerisinde pek fazla çalışmayla karşılaşılmamaktadır. (Türker, 2019).Bu alanda yapılan çalışmalar genellikle Okulöncesi, Hayat Bilgisi, Din Kültürü ve Ahlak Bilgisi, Türkçe ve Sosyal Bilgiler branşlarında yapılmaktadır (Şentürk, 2019).Araştırmalar gösteriyor ki değer eğitimi alanındaki çalışmalar bazı branşlarda sıklıkla yapılırken bazı branşlarda çok az yapılmakta, bazılarında hiç yapılmamaktadır. Değer eğitimini sadece belli dersler içerisinde vermek yanlış bir tutumdur. Değer eğitiminde yapılan araştırmalar genellikle Türkçe, Sosyal Bilgiler ve Din Kültürü derslerinde ağırlıklı olarak yapılıyor. Fen Bilimleri, Resim, Matematik ve Müzik derslerinde öğretmenler değer eğitimi konusunda daha az sorumlu tutulmaktadırlar (Herdem, 2016).

Çalışmalarda kullanılan araştırma yöntemleri analiz edildiğinde, tezlerde en fazla \%50 oranında nitel araştırma yönteminin en az ise \%21,1 oran ile karma araştırma yönteminin kullanıldığı belirlenmiştir. Bu durumun sebebinin değer eğitimi çalışmalarının nitel yöntemle daha iyi sonuç vermesi olabilir. Nitel yöntemi benimsemiş bir çalışmanın amacı, konu hakkında derinlemesine bilgi elde edebilmektir. Bu amaçla araştırmacı ek sorular sorarak katılımcının kişisel düşüncelerini öne çıkarmaya çalışır (Neuman, 2012).

Araştırma deseni; araştırmaya rehberlik eden yol, araştırma çerçevesinin tutarlı olmasını sağlayan strateji olarak tanımlanabilir. Araştırmaya dahil edilen tezlerde nitel araştırma yöntemine sahip olan çalışmalarda durum çalışması deseni oranı $\% 34,2$ ile en yüksek oranda kullanılmıştır. En düşük oranda \%2,6 ile kültür analizi deseni kullanılmıştır. Nitel araştırma desenlerinden olan kuram oluşturma çalışması deseninde bir çalışma bulunmamaktadır. Nicel çalışmalarda, tarama desenindeki çalışmalar \%21,1 ile, \%7,9 oranında yapılan deneysel desendeki çalışmalardan oransal olarak daha yüksektir. Deneysel çalışmaların tümü yarı deneysel çalışmalardır. Bu durumun sebebinin değer eğitimi araştırmalarında, değer eğitimdeki öğrenmenin ve bunun davranışa dönüşüp dönüşmediğini ölçmek kolay olmaması olabilir. Eğitim araştırmalarında sıklıkla kullanılan karma araştırma desenleri gömülü karma, açıklayıcı karma, keşfedici karma ve paralel karma olarak dörde ayrılır (Creswell, 2008). Açıklayıcı karma desenli çalışmalarda, nicel veriler toplanır daha sonra bu nicel verileri açıklayıcı hale getirmek için nitel veriler toplanmaya başlanır. Keşfedici karma desenli çalışmalarda, öncelikli olarak nitel veriler toplanır daha sonra bu nitel veriler arasındaki ilişkileri ortaya koymak için nicel veriler toplanmaya başlanır (Creswell \& Plano Clark, 2011). Paralel karma desenli çalışmalarda, nitel ve nicel veriler aynı anda toplanır ve eş zamanlı olarak analiz edilir. Gömülü karmada ise nitel veriler ve ya nicel veriler diğer veri türünü desteklemek için kullanılır (Fıratvd, 2014). Çalışmada karma çalışmaların büyük bir bölümü \%10,5 oran ile paralel karma desendedir. En düşük oranda ise $\% 2,6$ oran ile açıklayıcı karma kullanılmıştır. Araştırılan tezlerde keşfedici karma çalışma bulunmamaktadır. Ozan \& Köse (2014) öğretim programları ve öğretim alanında yapılan 340 araştırmayı inceledikleri çalışmalarında, araştırma desenlerinde nitel çalışmalarda durum çalışmalarının, nicel araştırmalarda tarama çalışmalarının, tarama çalışmalarında da betimsel tarama çalışmalarının sıkılıkla kullanıldığını belirtmişlerdir. Ozan ve Köse çalışmalarında karma çalışmalarda açıklayıcı ve keşfedici karma çalışmaların oldukça az olduğu sonucuna varmışlardır.

Tezlerde, çalışmaların örneklemi veya çalışma grubu olarak seçilen grupyada materyaller incelendiğinde öğretmenleri ve kaynak kitapları inceleyen çalışmaların oranı \%28,9 ile en yüksek, 
öğreci veliler üzerine yapılan çalışmalar ise en düşük \%2,6 oranda kalmıştır. Örneklem grubu olarak velilerin incelendiği araştırma sayısı oldukça azdır. Kapkın vd. (2018), 1991-2017 yılları arasında değerler eğitimi alanında yapılan tezleri inceledikleri çalışmalarında; öğrencilerle, öğretmenler ve yöneticiler ile yüksek oranda çalışıldığını ancak velilerle yapılan çalışmaların oldukça az olduğunu tespit etmişlerdir. Gündüz vd. (2017) çalışmalarında incelenen 54 doktora tezinden sadece 1 tanesinde velilerin incelendiğini belirtmişlerdir. Fen bilimlerine yönelik çalışmalarda örneklem olarak seçilen kaynak kitaplarının, değer eğitim açısından incelendiği çalışmada; çevre eğitimi konularında yer alan değer eğitimi etkinliklerinin yetersiz ve bu değerleri öğrencilere kazandırmaktan uzak olduğu sonucuna ulaşılmıştır (Laçin Şimşek, 2004).

Araştırmaya dahil edilen tezlerde, üzerinde durulan değer veya değer grubu; \%47,4 oran ile programlarda yer alan değerler olmuştur. Programlardaki değerleri işleyen çalışmalardan sonra oransal olarak sırasıyla kaynaklardaki değerler \%23,7, eğitimcilerin değer algılarını inceleyen araştırmalar ise \%15,8 oranında olmuştur. Fen Bilimleri öğretmenlerinin değer yargılarını inceleyen çalışmalara ve bazı fen projelerinin değer boyutunu araştıran çalışmalarla karşılaşmaktayız. Bu çalışmalarda fen projelerinde vatandaşlık bilinci ve vatanseverlik değeri incelenirken öğretmenlerin farklı değerler hakkında algıları ve görüşleri incelenmiştir (Aktaş \& Bozdoğan, 2016; Çeken vd, 2013; İdin \&Aydoğdu, 2017; Oğuz, 2012). Araştırmalarda doğrudan çalışılan değerler \%13,2 ile en az oranda işlenen değerler olmuştur. Doğrudan çalışılan değerler genellikle; sevgi, sayg1, sorumluluk, kök değerler ve adalet değerleri olmuştur. Fen bilimlerine yönelik yapılan bir çalışmada, fen bilimleri öğretmenlerinin kök değerler hakkındaki görüşleri alınmış ve değer öğretmede kullandıkları yöntemler belirlenmeye çalışılmış ve öğretmenlerin genellikle birkaç değer üzerinde durdukları, değer öğretmek için örnek olay, gezi, araştırmaya dayalı teknikleri kullandıkları sonuçlarına ulaşılmıştır (Gündüz \& Bağc1, 2019). Kapkın vd. (2018) çalışmalarına dahil ettikleri 113 araştırmada, en fazla çeşitli eserlerde var olan değerleri inceleyen çalışmalara ulaştıkları ve çalışmada en az oranda eğitimcilerin değer algılarını inceleyen çalışmalara ulaştıkları belirtilmiştir. Fen bilimleri öğretim programlarının değerler eğitimi bakımından incelendiği çalışmalarda, belli yıllara ait fen bilimleri öğretim programları karşılaştırılmış, bazı yıllara ait öğretim programları değer ve değer eğitimi açısından incelenmiştir. Bu çalışmalarda 2018 yılı öğretim programında 2013 yılı öğretim programından farklı kültürel, ahlaki ve evrensel değerlerin bulunduğunu, sorumluluk değerine en fazla 8. sinıf en az ise 5. sinıf kazanımlarında yer verildiği sonuçlarına ulaşılmıştır (Deveci, 2018; Gömleksiz \& Bulut, 2007; Demirci Güler \&Açıkgöz, 2019).

Alan yazında, analiz yöntemlerine göre incelenen tezlerde, farklı analiz yöntemlerinin kullanıldığı görülmüştür. Nitel çalışmalarda ve tüm çalışmalar içerisinde içerik analizi \%34,2 ile yüksek oranda kullanılmıştır. Nitel analiz türlerinden olan betimsel analizi kullanan çalışmalar \%10,5 oranı ile içerik analizine göre oldukça azdır. İki nitel çalışmada betimsel analiz ve içerik analizi beraber kullanılmıştır. Nicel çalışmaların çoğunda yalnız istatistiksel analizler kullanılırken, 2 nicel çalışmada betimsel analiz ve istatistiksel analizin kullanıldığ karma analiz kullanılmıştır. Gündüz vd. (2017), değer eğitimi alanında yapılan bu çalışmada, 54 doktora tezi incelenmiş ve analiz türleri açısından; 18 nitel, 13 nicel ve 23 karma çalışma yönteminin kullanıldığı bu çalışmada; 5 nitel, 22 nicel, 27 nitel ve nicel veri analizinin kullanıldığ 1 tespit edilmiştir. Bu tür çalışma sonuçları bize, farklı yöntemlere sahip araştırmalarda farklı analiz yöntemlerinin kullanılabileceğini göstermektedir.

Formda yer alan diğer araştırma konumuz, tezlerin öneriler bölümlerinin incelenmesidir. Milli Eğitim Bakanlığı'na ve Bakanlık dışına yapılan öneriler olarak iki kategori belirlenmiştir. Bakanlığa \%51,9 ve bakanlık dışına \%47,9 ile yapılan önerilerin oranları birbirine yakın olmakla beraber bakanlığa yapılan önerilerin oranı daha yüksektir. Bakanlığa yapılan öneriler incelenirse, en yüksek oranda $\% 20,4$ ile öğretim programlarıyla ilgili öneriler daha sonra kaynak kitaplara yönelik \%14,1, öğretmenlere yönelik eğitimler ve en düşük oranda $\% 6,2$ ile okullara yapılmas1 istenen teknik imkanlar ve materyal desteğiyle ile ilgili öneriler olmuştur. Mili Eğitim Bakanlığı 
dışında yapılan öneriler incelendiğinde ise en yüksek \%29,4 oran ile okul yönetimlerine ve öğretmenlere, \%6,9 oranında velilere yönelik, sonra Yükseköğretim kurumlarına ve en düşük oranda da çevreye yönelik önerilerin olduğu görülmüsstür. Bunun sebebi olarak incelenen tezlerin çalışma grupları (Tablo 5) ve çalışılan değer grupları (Tablo 6) sonuçları ile açıklanabilir. İncelenen tezlerin çalışma gruplarından en yüksek oranda öğretmen ve öğrencilerin görüşlerinin tespit edildiği ve kaynak kitapların incelendiği görülmektedir. Bununla birlikte çalışılan değer gruplarına bakılırsa, ders programlarındaki ve kaynak kitaplardaki değerler üzerine yapıldığı tespit edilmiştir. Dolayısıyla, öğretmen-öğrenci-program ve kaynak kitap durumları Milli Eğitim Bakanlığının temel paydaşları ve etkileşimleri olduğu için yapılan önerilerin de yüksek oranda Bakanlığa yönelik yapıldığını ortaya koymaktadır.

\section{Öneriler}

Araştırma sonuçlarına göre aşağıdaki önerilerde bulunulmuştur.

- Araştırmalar incelendiğinde örneklem grubu olarak velilerin incelendiği tezlerin sayısının oldukça az olduğu görülmüştür. Örneklem grubu olarak velilerin kullanılabileceği araştırmaların arttırılması önerilebilir.

- Yapılan çalışmada tezlerle ilgili verilerin toplanmasında 8adet sınıflama ile çözümlenmiştir. $\mathrm{Bu}$ alt problemler daha fazla sayıda veya farklı problemler ile çeşitlendirilerek yapılabilir. Örneğin sınıflama türü olarak "öğretim materyalleri” seçilir ve materyaller daha ayrıntılı incelenmesi yapılırsa, değerler eğitimine yönelik planlanan etkinlikler hakkında derinlemesine bilgi edinilebilir. Diğer bir sınıflama örneği, "öğrencilerin başarı ve davranışlarında meydana gelen değişimleri tespit etmede kullanılan değerlendirme teknikleri” üzerine olabilir. Böylece öğretmenlerin özellikle davranışsal boyutlardaki değerlendirme kriterleri tespit edilerek, değerler eğitimine katkı sağlanabilir.

- Araştırma kapsamında incelenen tezlerde, değer eğitimi bakımından, fen Bilimleri kaynak kitaplarını inceleyen bir teze rastlanmamıştır. Fen Bilimleri ders kitaplarına yönelik çalışma yapılması önerilebilir.

- Yapılan bu çalışmada, kullanılan formda yer alan sınıflamanın "öneriler" kısmında,"değer eğitimine" yönelik Milli eğitim Bakanlığımıza yapılan birçok öneri tespit edilmiştir. Bakanlığımızın tüm bu önerilerden haberdar olması oldukça elzemdir. Bu anlamda özellikle "öneri” sınıflandırması yapılan çalışmaların da desteklenmesi önerilebilir. Böylece bilgilerin bu tür çalışmalarla daha sistematik bir şekilde toplanabileceği düşünülmektedir.

- İncelenen tezler içerisinde disiplinler arası bir organizasyonla değer eğitimi vermeyi amaçlayan çalışma sayısı oldukça sınırlıdır. Bu çalışmaların sayısı artırılabilir.

- Yapılan çalışmalarda Fen Bilimleri ve Spor Bilimleri gibi alanlarda çalışmaların az olduğu görülmektedir. Özellikle, bilim-toplum-çevre ile birebir etkileşimi olan fen bilimleri dersine yönelik çalışmaların zenginleştirilmesi önerilebilir.

\section{Kaynakça}

Ağır, H. S. (2017). Illköğretim din kültürü ve ahlak bilgisi dersinde sorumluluk değeri ile ilgili kazanımların gerçekleşme düzeyi. [Yayımlanmamış yüksek lisans tezi]. Atatürk Üniversitesi Eğitim Bilimleri Enstitüsü.

Akbaş, O. (2008). Değer eğitimi akımlarına genel bir bakış. Değerler Eğitimi Dergisi, 6(16), 9-27. 
Aköz, T. (2018). Beden eğitimi ve spor derslerinde verilen değerler ĕgitiminin ögrencilerin olumlu sosyal davranış düzeylerine etkisinin incelenmesi.[Yayımlanmamış yüksek lisans tezi]. Ankara Üniversitesi Eğitim Bilimleri Enstitüsü.

Aktaş, Z.\& Bozdoğan, A. E. (2016). Fen bilimleri dersi "İnsan ve Çevre" ünitesiyle bütünleştirilmiş etkinliklerin ortaokul öğrencilerinin merhamet değerini kazanmalarına etkisi. Değerler Ĕgitimi Dergisi, 14(32), 3957.https://doi.org/10.17522/nefefmed.47683

Akyol, Ş. (2010). İlköğretim 6. sinıf Türkçe ders kitaplarında yer alan sevgi temasının değerler eğitimi açısından incelenmesi.[Yayımlanmamış yüksek lisans tezi]. Çanakkale Onsekizmart Üniversitesi Sosyal Bilimler Enstitüsü.

Altun, S. A. (2003). Eğitim yönetimi ve değerler. Değerler Ĕğitimi Dergisi, 1(1), 7 17.https://doi.org/10.14527/9786053189558.07

Ateş, F. (2013). Illkokul ve ortaokul ögretmenlerinin değerler ĕgitimi ve uygulamalarına yönelik görüşleri üzerine nitel bir araştırma [Yayımlanmamış yüksek lisans tezi]. Yeditepe Üniversitesi Sosyal Bilimler Enstitüsü.

Ayas, C., Çeçen, R., Eş, H. \& Taştan, B. (2013). "Bu benim eserim" fen bilimleri projelerinde vatandaşılı eğitimi açısından sosyal sorumluluk ve vatandaşlık bilinci. Adıyaman Üniversitesi Sosyal Bilimler Estitüsü Dergisi, 6(14).https://doi.org/10.14520/adyusbd.587

Balc1, N. (2008). İlköğretim 6. sinıf sosyal bilgiler dersinde değer ĕgitiminin etkililiği.[Yayımlanmamış yüksek lisans tezi]. Marmara Üniversitesi Eğitim Bilimleri Enstitüsü.

Başc1, Z. (2012). Beşinci sınıf sosyal bilgiler dersinde değer eğitiminin öğretmen görüşlerine göre incelenmesi (Erzurum örneği) [Yayımlanmamış doktora tezi]. Atatürk Üniversitesi Eğitim Bilimleri Entütüsü.

Baysal, N. (2013). Ortaokul sosyal bilgiler derslerinde değerler eğitimi uygulamalarının ögretmenler yönüyle değerlendirilmesi. [Yayımlanmış yüksek lisans tezi]. Niğde Üniversitesi Eğitim Bİlimleri Enstitüsü.

Baytaş, S. H. (2019). Illköğretim Türkçe ders kitaplarındaki çocuk edebiyatı metinlerinde moral değerler sistemi (5, 6, 7, 8. Sinıf/ 2005-2017). [Yayımlanmamış yüksek lisans tezi]. Çanakkale Onsekiz Mart Üniversitesi Eğitim Bilimleri Enstitüsü.

Büyüköztürk, Ş., Kılıç Çakmak, E., Aygün, E., Karadeniz, Ş.\& Demirel, F. (2019). Eğitimde bilimsel araştırma yöntemleri. Pegem Akademi.

Creswell, J. (2008). Educational research planning, conducting and evaluating quantitative and qualitative research.International Pearson Merril Prentice Hall.

Creswell, J. \& Plano Clark, V. (2011). Designing and conducting mixed methods research. Sage.

Çakmak, Ö. (2019). 5. Sinıf düzeyinde hazırlanan değer eğitimi etkinliklerinin uygulanabilirliği ve başarısı üzerine bir durum çalışması [Yayımlanmamış yüksek lisans tezi]. Sakarya Üniversitesi Eğitim Bilimleri Enstitüsü.

Çiçen, M. E. (2019). Değer ĕgitimi temelli drama programının 6. Sinıf öğrencilerinin demokratik değerleri. [Yayımlanmamış yüksek lisans tezi]. Gazi Üniversitesi Eğitim Bilimleri Enstitüsü. 
Çüçen, A. (2011). Derin Ekoloji. websitem.karatekin.edu.tr: https://websitem.karatekin.edu.tr/user_files/bdemirbilek/files/20191005_d19049be260c4a2 e90ad9acebf71b3c6.pdf

Demirci Güler, M. P. \& Açıkgöz, S. N. (2019). 2018 Yılı Fen Bilimleri dersi öğretim programının sorumluluk kazanımlarına yer vermesi bakımından incelenmesi. Eğitimde Nitel Araştırmalar Dergisi, 7(1), 391-419.https://doi.org/10.15285/maruaebd.525249

Deveci, İ. (2018). Türkiye'de 2013 ve 2018 y1lı Fen Bilimleri dersi öğretim programlarının temel öğeler açısından karşılaştırılması. Mersin Üniversitesi Eğitim Fakültesi Dergisi, 14(2), 799825.https://doi.org/10.17860/mersinefd.342260

Dinçer, B.\& Gözel, Ü. (2019). İlkokul programlarında (1-4) yer alan ve kazandırılması hedef değerlere ilişkin sınıf öğretmenlerinin ve öğrenci velilerinin görüşlerinin incelenmesi. Değerler Ĕ̈itimi Dergisi, 17(38), 207-234.https://doi.org/10.34234/ded.536439

Doğanay, A. (2006). Değerler eğitimi. Cemil Öztürk (Ed.). Hayat Bilgisi ve Sosyal Bilgiler Öğretimi Yapılandırmacı Bir Yaklaşım içinde. (2. Baskı). 255-286. Pegem A Yayıncılık.

Ecerkale, N. (2019). Meb yayınları Türkçe 7. ve 8. Sinıf ders kitabındaki metinlerin değerler bağlamında incelenmesi. [Yayımlanmamış yüksek lisans tezi]. Fırat Üniversitesi Eğitim Bilimleri Enstitüsü.

Engin, G. (2014). Türkçe ve beden ĕgitimi ögretim programlart ile bütünleştirilmiş değerler eğitimi programının etkililiği [Yayımlanmamış doktora tezi]. Çanakkale Onsekiz Mart Üniversitesi Eğitim Bilimleri Enstütüsü.

Erbir, B. \& Bağc1, C. (2013). Değerler eğitimi üzerine yapılmış lisansüstü düzeyindeki çalışmaların değerlendirilmesi. Electronic Türkish Studies, 8(1), 1321-1333.

Ertürk, İ. B. (2019). Din kültürü ve Ahlak Bilgisi derslerinde Allah'a iman penceresinden değerler eğitimi. [Yayımlanmamış yüksek lisans tezi]. Sakarya Üniversitesi Eğitim Bilimleri Enstitüsü.

Fırat, M., Kabakcı Yandul, I. \& Ersoy, A. (2014). Bir eğitim teknolojisi araştırmasına dayalı olarak karma yöntem araştırması deneyimi. Eğitimde Nitel Araştırmalar Dergisi, 2(1), 6586.https://doi.org/10.14689/issn.2148-2624.1.2s3m

Göçmen, G. B. (2009). Meta- analizin genel bir değerlendirmesi. Sakarya Üniversitesi Eğitim Fakültesi Dergisi, 17(4), 345-360.

Gömleksiz, M. N.\& Bulut , İ. (2007). Yeni fen ve teknoloji dersi öğretim programının uygulamadaki etkililiğinin değerlendirilmesi. Hacettepe Üniversitesi Eğitim Fakültesi Dergisi, 32(32), 76-88.https://doi.org/10.14686/201312029

Görgüt, İ. (2015). Ortaokullarda görev yapan beden eğitimi ve diğer branş ögretmenlerinin ahlak, karakter ve değerler eğitimine ilişkin görüşlerinin incelenmesi.[Yayımlanmamış doktora tezi ]. Gazi Üniversitesi Eğitim Bilimleri Enstitüsü.

Gündüz, M., Başpınar, Z. \& Büyükkarcı, A. (2017). 2000-2015 yılları arasında değer eğitimi üzerine yapılan doktora tezlerinin içerik analizi. Dicle Üniversitesi Ziya Gökalp Eğitim Fkültesi Dergisi,(31), 705-718.https://doi.org/10.14582/duzgef.1817

Gündüz, M. \& Bağcı, M. (2019). Fen Bilgisi öğretmenlerine göre kazanımlardaki kök değerler ve değerleri öğretme yöntemlerinin incelenmesi. Uluslararası Sosyal Bilimler Eğitimi Dergisi, 5(2), 184-197.https://doi.org/10.20860/ijoses.621559 
Herdem, K. (2016). Yedinci sınıf fen bilimleri dersi konularlyla bütünleştirilmiş değerler eğitimi etkinliklerinin ögrencilerin değer gelişimine etkisi. [Yayımlanmamış yüksek lisans tezi]. Adıyaman Üniversitesi Fen Bilimleri Enstitüsü.

İdin, Ş. \& Aydoğdu, C. (2017). Fen bilimleri öğretmenlerinin sosyal adalet ve eşitlik perspektifinde fen bilimleri eğitimine ilişkin görüşler. Abant İzzet Baysal Üniversitesi Ĕ̈itim Fakültesi Dergisi, 17(3), 1328-1349.https://doi.org/10.17240/aibuefd.2017.17.31178-338834

Kağıtçıbaşi, Ç. \& Kuşdil, M. (2000). Türk öğretmenlerin değer yönelimleri ve Schwartz değer kuramı. Türk Pisikolojisi Dergisi, 15(45), 59-80.

Kahya, A. (2018). Ortaokul Türkçe ders kitaplarındaki etkinliklerin değerler eğitimi bakımından incelenmesi. [Yayımlanmamış yüksek lisans tezi]. Uşak Üniversitesi Eğitim Bilimleri Enstitüsü.

Kantar, Ş. (2014). İlköğretim 4. Ve 5. sinıf Sosyal Bilgiler dersinde 100 temel eser yoluyla değerler eğitimi. [Yayımlanmamış yüksek lisans tezi]. Necmettin Erbakan Üniversitesi Eğitim Bilimleri Enstitüsü.

Kapkın, B., Çalışkan , Z. \& Sağlam, M. (2018). Türkiye'de 1999-2017 yılları arasında değerler eğitimi alanında yapılmış lisansüstü çalışmaların incelenmesi. Değerler Eğitimi Dergisi, 183-207.https://doi.org/10.21666/muefd.485737

Karacaoğlu, H. (2018). Dijital hikâyelerin Türkçe dersi değerler eğitimine yönelik etkisinin incelenmesi. [Yayımlanmamış yüksek lisans tezi]. Erciyes Üniversitesi Eğitim Bilimleri Enstitüsü.

Karataş, Z. (2015). Sosyal Bilimlerde nitel araştırma yöntemleri. Manevi Temelli Sosyal Hizmet Araştırmaları Dergisi, 1(1).https://doi.org/10.21560/spcd.vi.460937

Katılmış, A. (2010). Sosyal bilgiler derslerindeki bazı değerlerin kazandırılmasına yönelik bir karakter eğitimi programının geliştirilmesi.[Yayımlanmamış doktora tezi]. Marmara Üniversitesi Eğitim Bilimleri Enstitüsü.

Kılcan, B. (2009). Illköğretim 6. sinıf sosyal bilgiler öğretim programında yer alan değerler ögretimine ilişskin öğretmen görüşleri ( Kırş̧ehir ili örneği ). [Yayımlanmamış yüksek lisans tezi]. Niğde Üniversitesi Sosyal Bilimler Enstitüsü.

Koç, S. (2015). Ortaokul öğretmenlerinin değerler eğitimi konusundaki görüşleri. Kırıkkale Üniversitesi II.Ulusal (Uluslarası katılımlı) değerler eğitimi kongresi.

Maden, K. (2017). İlköğretim din kültürü ve ahlak bilgisi öğretim programında saygı değerinin yeri. [Yayımlanmamış yüksek lisans tezi]. Atatürk Üniversitesi Eğitim Bİlimleri Enstitüsü.

MEB. (2018). Fen Bililmleri öğretim programı (ilkokul ve ortaokul 3,4,5,6, 7,8.sinıflar). MEB.

Neuman, W. L. (2012). Toplumsal araştırma yöntemleri: nicel ve nitel yaklaşımlar I-II. Cilt (5. Basım). Yayın Odası.

Oğuz, E. (2012). Öğretmen adaylarının değerler ve değerler eğitimine ilişkin görüşleri. Kuram ve Uygulamadaki Eğitim Bilimleri, 12(2),1309-1325.https://doi.org/10.17121/ressjournal.1448

Ozan, C. \& Köse, E. (2014). Eğitim programları ve öğretim alanındaki araştırma eğilimleri. Sakarya University Journal of Education, 4(1), 116136.https://doi.org/10.19126/suje.76547 
Özcan, H. (2019). Trabzon ilinde en çok satılan çocuk kitaplarındaki değerler ile Türkçe ders kitaplarındaki metinlerin içerdiği değerlerin karşılaştırılması [Yayımlanmamış yüksek lisans tezi]. Trabzon Üniversitesi Lisansüstü Eğitim Enstitüsü.

Özdamar, G. (2017). Beden eğitimi ögretmenlerinin mesleki değer yönelimleri ve öğrencileri tarafindan algılanan disiplin sağlama stratejilerinin incelenmesi [Yayımlanmamıs yüksek lisans tezi]. Mersin Üniversitesi Eğitim Bilimleri Enstitüsü.

Özdaş, F. (2013). Ortaokullarda değerler eğitimi ve istenmeyen öğrenci davranışlarına ilişkin ögretmen görüsslerinin değerlendirilmesi. [Yayımlanmamış doktora tezi ]. Fırat Üniversitesi Eğüitim Bilimleri Enstitüsü.

Özenç, A. (2019). Ortaokul matematik ders kitaplarında yer alan matematiksel değerlerin ve matematik ĕgitimi değerlerinin incelenmesi. [Yayımlanmamış yüksek lisans tezi]. Dicle Üniversitesi Eğitim Bilimleri Enstitüsü.

Özkemahlı, S. (2019). II Kademe görsel sanatlar dersi öğretmenlerinin değerler eğitiminin etkileri üzerine görüşleri: samsun ili örneği. [Yayımlanmamış yüksek lisans tezi]. Ondokuz Mayıs Üniversitesi Eğitim Bilimleri Enstitüsü.

Saka, S. (2014). Fen ve Teknoloji dersi ile Din Kültürü ve Ahlak Bilgisi dersi ögretim programındaki ortak değerlerin karşılaştırılması. [Yayımlanmamış yükssek lisans tezi]. Düzce Üniversitesi Sosyal Bilimler Enstitüsü.

Serikkhankyzy, S. (2018). Türkiye ve Kazakistan'da okutulan 6. Sinıf Türkçe, Kazak edebiyatı ve Rus edebiyatı ders kitaplarının değerler açısından incelenmesi. [Yayımlanmamış yüksek lisans tezi]. Erzincan Binali Yıldırım Üniversitesi Eğitim Bilimleri Enstitüsü.

Sezer, T. (2008). İlköğretim 6. sinıf Sosyal Bilgiler dersinde sorumluluk değerinin ögretimine ilişskin ögretmen görüşleri.[Yayımlanmamış yüksek lisans tezi]. Gazi Üniversitesi Eğitim Bilimleri Enstitüsü.

Şahin, S. (2019). Türkçe dersi öğretim programı'nda yer alan kök değerler açısından Rafadan Tayfa çizgi filminin incelenmesi. [Yayımlanmamış yüksek lisans tezi]. Bolu Abant İzzet Baysal Üniversitesi Eğitim Blimleri Enstitüsü.

Şahin, T. (2013). Sosyal Bilgiler öğretmen adaylarının değerler eğitimi öz-yeterliliklerinin incelenmesi. [Yayımlanmamış yüksek lisans tezi]. Marmara Üniversitesi Eğitim Bilimleri Fakültesi.

Şentürk, G. (2019). Fen bilimleri dersinde değerler eğitiminin uygulanabilirliğine iliş̧kin öğretmen görüşleri. [Yayımlanmamış yükssek lisans tezi]. Yıldız Teknik Üniversitesi Fen Bilimleri Enstitüsü.

Şimşek, C. (2004). Fen bilgisi öğretim programı ve ders kitaplarına göre çevre eğitiminde etik ve estetik değerle. Değerler Eğitimi Dergisi, 2(7), 127 146.https://doi.org/10.17522/nefefmed.47683

Taymur, N. (2019). Güncellenen Görsel Sanatlar dersi ögretim programının değerler ĕgitimine ilişkin kavramları ögretmedeki etkisi üzerine ögretmen görüşleri. [Yayımlanmamış yüksek lisans tezi]. Kütahya Dumlupınar Üniversitesi Sosyal Bilimleri Enstitüsü.

Toktemir, M. A. (2007). Tarih öğretmenlerinin değerler dĕger ĕgitimi hakkındaki görüşleri. [Yayımlanmamış yüksek lisans tezi]. Kardeniz Teknik Üniversitesi. 
Türker, A.(2019). Fen Bilgisi Öğretmen adaylarının değer yargılarının incelenmesi, [Yayımlanmamış Yüksek Lisans Tezi]. Burdur Mehmet Akif Ersoy Üniversitesi Eğitim Bilimleri Enstitüsü.

Uğurlu, M. (2012). İlköğretim 7. Sinıf sosyal bilgiler ögretim programında yer alan değerlerin kazanılmışlık düzeyinin veli görüşlerine göre değerlendirilmesi. [Yayımlanmamış yükssek lisans tezi]. Kastamonu Üniversitesi Sosyal Bilimler Enstitüsü.

Uğurlu, Z. (2019). Illköğretim din kültürü ve ahlak bilgisi ögretim programı 7. sinıf "din ve güzel ahlak" ünitesindeki ahlaki değerlerle ilgili drama yöntemi uygulamaları. [Yayımlanmamış yüksek lisans tezi]. Ondokuz Mayıs Üniversitesi Sosyal Bilimleri Enstitüsü.

Ulusoy, K. (2010). Değer eğitimi: davranışçı ve yapılandırmacı yaklaşıma göre hazırlanan tarih programlarında değer aktarımı. Trakya Üniversitesi Sosyal Bilimler Dergisi, 12(1), 3251.https://doi.org/10.17494/ogusbd.555477

Yazıcı, D. (2006). Değerler eğitimi'ne genel bir bakış. Türklük Bilim Araştırmaları, (19), 499-522.

Yıldız, M. (2019). Ortaokul Matematik ders kitaplarındaki metin ve görsellerin değerler açısından incelenmesi. [Yayımlanmamış yüksek lisans tezi]. Zonguldak Bülent Eceviz Üniversitesi Fen Bilimleri Enstitüsü.

Yurtsever, T. (2018). Değerler sosyolojisi açısından din kültürü ve ahlak bilgisi ders müfredatının analizi. [Yayımlanmamış yüksek lisans tezi]. Kırıkkale Üniversitesi Sosyal Bilimler Enstitüsü. 